\title{
Problematic aspects of consumer protection in the conditions of introduction of restrictive measures
}

\author{
Irina Soshnikova, Oksana Trotsenko* and Roman Galigin \\ Ural State University of Economics, Narodnoy Voli 45/62 Str., 620144 Yekaterinburg, Russia
}

\begin{abstract}
The article considers the history and concept of a retail sale and purchase agreement, specific features of a retail sale and purchase agreement, features and grounds for classifying a retail sale and purchase agreement, and will give a general theoretical and legal description of the types of retail sale, and also analyzes the problems of the execution of the retail sale and purchase agreement in the context of the introduction of restrictive measures.
\end{abstract}

\section{Introduction}

The relevance of the article is determined by the low legal literacy of ordinary citizens, consumers, which negatively affects the development of healthy market competition due to the lack of desire of manufacturers to make the product better, due to the legal infantilism of citizens-consumers. As can be seen in Figure 1, the number of civil cases in federal courts of general jurisdiction and magistrates' courts of first instance is annually decreasing by $8-11 \%$.

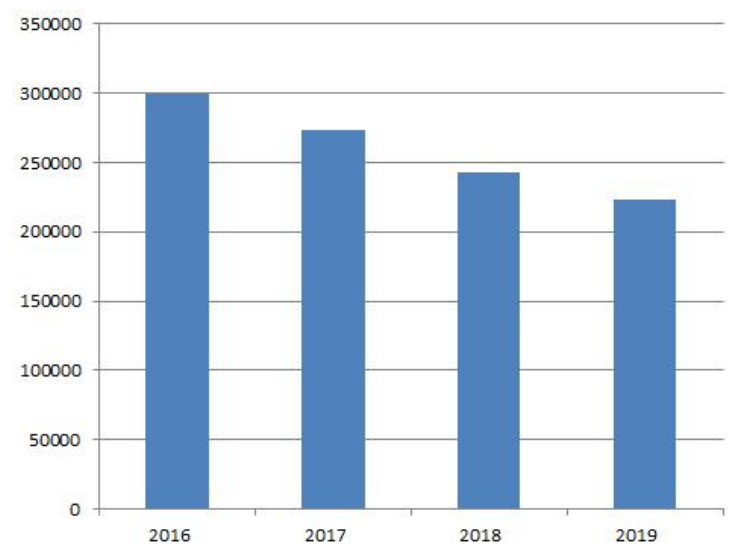

Fig. 1. Comparative analysis of the number of civil cases submitted to federal courts of general jurisdiction and magistrates' courts at first instance

*Corresponding author: trocenko.o@mail.ru 
Also, it should be noted that the retail sale and purchase agreement is the most widespread among all contractual structures, since almost every day every citizen is a party to it.

The design of the retail sale and purchase agreement is relatively young, therefore, under the influence of the development of civil turnover, and despite the fact that the retail sale and purchase agreement has been withdrawn into a separate category of sales and purchase agreements, and a special legal regime has been created for this category of agreements, it is necessary to continue to improve legal regulation of relations between subjects of retail trade [7, p. 47-49].

Civil law experts from the Russian Federation devoted their works to the problems of the retail sale and purchase agreement and its types. Among the authors who analyzed the legal nature and classification of the retail sale and purchase agreement, one can mention I.B. Novitsky, V.E. Rubanik, M.I.Braginsky, O.S. Ioffe, E.V. Ivanova and others .

\section{Materials and Methods}

The introduction of new forms of payment into civil circulation, the denationalization of the property of public entities, the introduction into civil circulation of such specific methods of retail trade as a remote method of sale, sale of goods according to samples, a hire-sale agreement, the development of sales through vending machines determines the importance of researching this topic at the present stage [8, p.298].

The goal of the article is to analyze the legal nature of the retail sale and purchase agreement and ways to protect consumer rights.

To achieve this goal, the following tasks were set.

1. To consider the history and concept of a retail sale and purchase agreement;

2. To consider the specific features of the retail sale and purchase agreement;

3. To consider the features and grounds for the classification of the retail sale and purchase agreement;

4. To give a general theoretical and legal description of the types of retail purchase and sale;

5. To research the official statistics and to identify problems in the consumer protection system.

The object of the research is social relations arising in the sphere of civil turnover in the process of retail sale and purchase.

The subject of the research is the legal regulation of retail purchase and sale, theoretical ideas of scientists about the concept and problems in the system of consumer protection.

\section{Results and Discussion}

During the research, general scientific and special methods of scientific knowledge were used. The methodological basis of the research is the dialectical method of cognition. It was possible to determine the place of the retail sale and purchase agreement in the system of civil contracts, to classify the forms of retail sale and purchase using the method of systemstructural analysis.

The analysis of the provisions of the current legislation was carried out using formal logical and formal dogmatic methods. The comparative legal method was applied and used for the purpose of conducting a comparative analysis of the norms of the current legislation.

The origin of the sale and purchase is rooted in me. This initial form of exchange transactions was replaced by the exchange of goods for money. The further development of property relations led to such an agreement when the immediate transfer of the goods, on 
the one hand, the price, on the other hand, might not have happened, that is, they began to conclude an agreement under which the parties assume mutual obligations: one is to transfer the goods, the other - to pay the price for it.

The very concept of «contract» was enshrined in article 1101 of the Napoleon Code: «A contract is an agreement by which one or more persons are obliged to another person or to several persons to give something, to do something or not to do something». In turn, the Napoleon Code also secured the freedom of citizens to dispose of their property, along with the freedom to conclude contracts, including the basic principles of civil law.

According to Russkaya Pravda, the sale and purchase agreement was concluded in front of witnesses, i.e. representative of the prince. The Paper of Vladimir Monomakh speaks of self-sale, a free person into slaves.

Although in the days of Ancient Russsia the term «agreement» did not yet exist, the procedure for its conclusion was quite simple. At that time, a contract was understood as an agreement between two or more persons, as a result of which rights and obligations arose. Contracts, as a rule, were concluded orally in the form of symbolic rites and the presence of witnesses.

In Russkaya Pravda there is an article, the content of which seems to speak about the conditions of the contract for the sale and purchase of other items: "Whether it will be something that you bought in the auction, or a horse, or a port, or cattle, then you will bring a husband two or a mytnik free; Even if he does not start from the nobility from whom he bought it, then follow him with that look at the company, and take your face with the truth $[11$, p. 275].

We agree with the words of Professor M.I. Braginsky: «... the restructuring of civil legislation inevitably demanded the same restructuring and the science of law of the same name. This was largely due to changes to the centuries-old domestic doctrine of civil law with the recognition of the need to study along with our own, as well as the experience of other countries. Under these conditions, interest in Roman law as the source of modern private law increased» [3, p. 275].

In the legal literature of the 20th century, the use of the purchase and sale agreement was explained by the fact that «under socialism, the operation of the law of value is combined with the operation of the law of proportional development and the basic economic law of socialist society. As a result, the law of value loses its universal significance, and therefore the scope of application of the contract of sale, which is used mainly for the sale of consumer goods and only on a relatively small scale for the sale of means of production, is limited» [6, p. 206].

The sales contract is not only the oldest, but also one of the most important institutions of civil law. For several millennia, there has been a natural selection of the rules of the sales contract.

Global changes in the scope and use of the sale and purchase agreement are associated with economic reforms in Russia, with significant changes in the economic basis of Russian society. The 1993 Constitution of the Russian Federation determined the right of citizens and legal entities to free economic activity in accordance with Article 37.

When developing the new Civil Code of the Russian Federation, the development trend of the scope of the institution of sale and purchase was taken into account, which at that time already determined the relations associated with the contracting of agricultural products, and with the supply of energy and other resources, and with the supply of goods. Compared to the Civil Code of the RSFSR of 1964, the content of the rules of purchase and sale has been significantly enriched. Such type of purchase and sale as retail purchase and sale stood out in a separate category.

The Consumer Protection Law applies to relations under a retail sale contract involving a citizen buyer that is not regulated by the Civil Code. 
The main difference between a retail sale and purchase agreement from other sales and purchase agreements is the intended purpose of the item being sold, namely, its use only for personal, family, household and other purposes not related to entrepreneurial activity. Separating the retail sales contract into a separate category is necessary in order to legislatively protect the consumer.

To date, in addition to the Civil Code of the Russian Federation, the legal relationship of the parties under the retail sale and purchase agreement is regulated by the Federal Law of 02/07/1992 N 2300-1 «On Protection of Consumer Rights», Resolution of the Government of the Russian Federation of 01.19. 1998 N 55 «On approval of the Rules for the sale of certain types of goods, the list of durable goods that are not subject to the buyer's requirement to provide him with a free provision of similar goods for the period of repair or replacement, and a list of non-food goods of good quality, not subject to return or exchange for a similar product of other size, shape, dimension, style, color or configuration», Resolution of the Government of the Russian Federation of 10.11.2011 N 924 «On approval of the list of technically complex goods».

Why is it necessary to legally provide the consumer with additional rights? First of all, this is due to the special subject composition of the retail sale and purchase agreement. On the one hand, the seller must be an entrepreneur (individual entrepreneur or commercial organization); on the other hand, the buyer can be not only a citizen, but also a legal entity (in those cases when it comes to the functioning of, for example, the buyer's office).

The citizen buyer does not have certain specific knowledge, is not able to distinguish between proper and inappropriate technically complex goods at first glance, has a unique perception system that is different from other people. In this case, the provisions of the Law «On Protection of Consumer Rights» and other legal acts adopted in accordance with it («Rules for the sale of certain types of goods", "Rules for the sale of goods by samples», etc.) are applied. These regulatory legal acts allow to achieve a balance in the legal relationship between the seller and the buyer.

In addition to the special subject composition, the intended purpose of the item being sold, specific legislative regulation, the retail sale and purchase agreement, in accordance with Part 2 of Article 492 of the Civil Code of the Russian Federation, is a public agreement, which means that a legal entity or an individual entrepreneur who are parties to a public agreement, can not refuse everyone who turned to her to conclude a contract, except in the absence of the necessary goods [13].

The separation of the sale of goods by samples and the remote method of sale into separate types of retail sale and purchase allows to regulate in a special way the legal relations of the subjects of retail sale. So, in accordance with Article 26.1 of the Law «On Protection of Consumer Rights», the consumer receives an additional right to refuse the goods at any time before its transfer and within 7 days after the transfer.

The peculiarity of the lease-sale agreement is that it contains the features of both the purchase agreement and the lease agreement. The product can be sold on a postpaid basis. In other words, «I sell you the goods in installments, the ownership of the goods remains with me until full (or partial) payment, and you can use the goods even now».

Unfortunately, the lease and sale agreement was undeservedly forgotten by many specialists. The complex combination of elements of lease and sale, lack of relevant court practice and gaps in legal science - all this made it difficult to use.

What are the benefits for the parties by entering into a sales contract?

The seller significantly reduces his risks associated with the possible insolvency of the buyer. Indeed, in case of non-payment of the redemption amount, as a general rule, the goods are returned to the seller. However, the seller should pay attention to the fact that in case of payment of 50 percent of the redemption amount, the seller is not entitled to demand the return of the goods in kind. 
The buyer acquires the right to use the product long before full payment for it. At the same time, he is exempted from the costs typical for lease relations.

The seller, in the event of the conclusion of this agreement, reflects payments as advance for the purchase and sale of real estate, without charging VAT on the amount of actual lease payments. The buyer can record his actual rental payments as a capital investment.

It can be concluded that the division of the retail sale and purchase agreement into types is necessary in order to take into account all the subtleties and nuances that arise in the field of retail sale, whether it is delivery of goods or a contract of hire and sale, sale of goods through an automatic machine or remote way of selling the product.

If the seller has not fulfilled his obligations or has performed them improperly, then in the future he will bear the adverse consequences provided for by the general provisions on the sales contract.

In cases of retail purchase and sale, the seller will be subject to special rules on the consequences of breach of contract if he transferred to the buyer a product that does not meet the requirements for such a product.

In the event that the seller sells to the buyer goods of inadequate quality, a special rule is applied (Article 503 of the Civil Code of the Russian Federation), and not the general rule (Article 475 of the Civil Code of the Russian Federation)

Regarding what is a product of inadequate quality, it should be said that a product of inadequate quality is a product that has flaws.

Depending on the nature, flaws can be divided into two types - latent and explicit.

Obvious shortcomings are such shortcomings that can be discovered during the inspection of the goods or by using special methods, for example, by connecting the goods to the mains (connecting an electric saving light bulb to the mains in the store at the checkout, etc.).

Hidden flaws are those flaws that can only be discovered during the operation or storage of the goods.

If the seller is aware of the obvious or hidden defects of the goods, then he is obliged to notify the buyer about this. Sometimes, this type of clause can also follow from the nature of the sale, for example, if a second-hand product is being sold.

In addition to the usual disadvantages, there are also significant disadvantages of the product.

If, after purchasing the goods, the buyer nevertheless found shortcomings that he was not properly notified of, then negative (in material terms) legal consequences ensue for the seller, which are provided for by Part 1 of Article 503 of the Civil Code of the Russian Federation.

If there is a discrepancy in price when replacing an inappropriate product with a product of proper quality or a similar product, a recalculation must be made in accordance with Article 504 of the Civil Code of the Russian Federation.

Also, there are exceptions to the general rule for replacing goods of inadequate quality:

1. Expensive and technically complex goods;

2. Goods that cannot be replaced due to their nature or nature of the obligation.

Regarding the first exception - in accordance with paragraph 1 of Article 18 of the Law on the Protection of Consumer Rights, the Government of the Russian Federation determines a list of technically complex goods that can be replaced only if there are significant deficiencies.

As for the second exception, the Civil Code of the Russian Federation does not provide for a period during which the seller must replace the goods. In this regard, both individual entrepreneurs and organizations should proceed from the provisions of Article 314 of the Civil Code of the Russian Federation, which determines the deadline for the fulfillment of 
the obligation, and as for citizens-consumers, they should be guided by the terms specified in Article 21 of the Law on the Protection of Consumer Rights, since there, as a general rule, a seven-day period for replacing goods of inadequate quality is determined [12].

Also, there is a list of goods that cannot be provided to the buyer as a replacement. This list was approved by the Decree of the Government of the Russian Federation of 01.19.1008 N 55 .

This list includes: electrical household appliances that are used for medical purposes and are used as toilet items (electric shavers, hair curlers, etc.), cars, numbered units and trailers, watercraft and pleasure boats, electrical household appliances that are intended for use as a heat treatment of food or cooking [10].

If the seller did not satisfy the buyer's claims regarding the inappropriate goods within the above timeframes and specified in the Civil Code of the Russian Federation and the Law on the Protection of Consumer Rights, then the buyer has the right to present to the seller any of the four previously described claims specified in Article 504 of the Civil Code of the Russian Federation.

An exception is the statement by the buyer of claims after 2 years from the date of purchase of the goods and by this time the warranty period has expired. In this case, the consumer will have to prove that the deficiency identified by him is significant and that it arose before the transfer of the goods to the consumer or for reasons that arose before that moment [2, p. 103-106].

The seller may refuse to satisfy the buyer's requirements if the buyer does not notify the seller about the inadequate quality of the goods within the time period established by law, agreement and other legal acts.

\section{Conclusions}

1. Summing up the intermediate result, we can say that the seller, in accordance with the current legislation, bears full financial responsibility for the quality of the goods sold. It should be noted that the number of civil cases submitted to federal courts of general jurisdiction and magistrates' courts at first instance is decreasing from year to year. In addition, the number of cases with a decision on satisfying claims is also decreasing $[4, \mathrm{p}$. 13-15]. According to the Judicial Department at the Supreme Court of the Russian Federation, it decreased by 28.81 percent. At the same time, the ratio of cases with a decision to satisfy claims for all received cases decreased by 3.18 percentage points over 4 years. If in 2016 the ratio of cases with a decision on satisfying claims for all received cases was 71.41 percent, then in 2019 the same ratio was 68.23 percent.

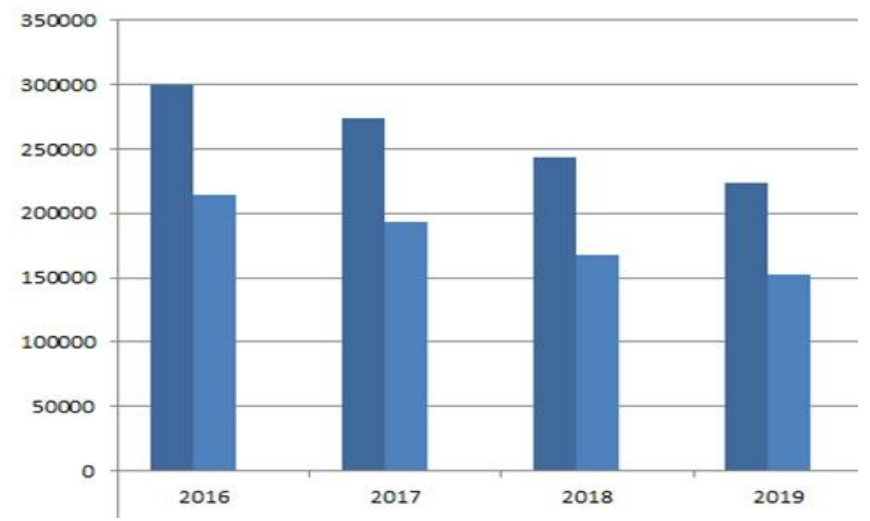

Fig. 2. Compiled by the author based on the data of judicial statistics - Moscow, 2020 
2. Analysts 'data indicate a decrease in the number of civil cases in federal courts of general jurisdiction and magistrates' courts at first instance, but do not talk about the reasons for this decrease [9, p. 102-104].

The reasons can be completely different. You can distinguish both positive and negative. But this division is subjective.

3. The positive reasons for the decrease in the number of civil cases in federal courts of general jurisdiction and magistrates' courts at first instance include:

1) development of the institution of pre-trial settlement of civil disputes on the protection of consumer rights related to the sale of goods in a claim procedure;

2) an increase in the mass of quality goods in the consumer market and a decrease in the mass of goods of inadequate quality;

Negative reasons include:

1) decrease in legal literacy of consumer citizens;

2) decreased confidence in the judicial system of the Russian Federation.

Also, you should pay attention to the analysis of statistics from the Google Trends service for a search query from the territory of the Russian Federation "Return goods" in Figure 3.

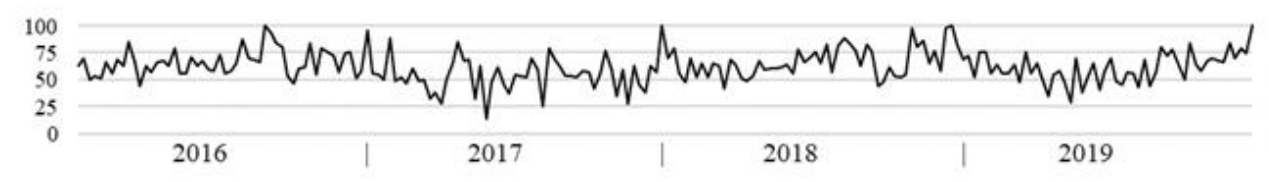

Fig. 3. Dynamics of the popularity of the search query "Return goods"

According to the graph, the popularity of the search query "Return goods" in the territory of the Russian Federation can be assessed as "Above average" and "High". Accordingly, an increase in the mass of quality goods in the consumer market and a decrease in the mass of goods of inadequate quality, as a reason for a decrease in the number of civil cases in federal courts of general jurisdiction and magistrates' courts at first instance, can be excluded [1, 123-130].

4. This suggests a conclusion about the need to increase citizens' confidence in the judicial system of the Russian Federation and the development of legal literacy of citizensconsumers, since this is an explicit demand from the population. Based on the results of the research work, the following were considered: the history and concept of the retail sale and purchase agreement; specific features of the retail sales contract; features and grounds for the classification of a retail sale and purchase agreement; the general theoretical and legal characteristics of the types of retail purchase and sale are given; investigated official statistics and identified problems in the consumer protection system.

Thus, the goal of the research work was achieved - the legal nature of the retail sale and purchase agreement and the ways of protecting consumer rights were analyzed [5, p. 21 24].

In the conclusion of the study, the following main conclusions on the topic can be drawn.

Citizens-consumers have low legal literacy, the consequence of this is their inability to fully use existing legal instruments, which leads to the development of legal infantilism. Legal infantilism of consumer citizens reduces the development of healthy competition in the consumer goods market.

The considered features of the retail sale and purchase agreement make it possible to distinguish it from the general mass of contractual legal relations and apply special legal instruments. 


\section{References}

1. N. A. Ablyatipova, A. A. Kravtsova, Bulletin of VolSU, 1 (2019)

2. A. A. Belskaya, Bulletin of RUK, 2(32) (2018)

3. M. I. Braginsky, Topical issues of civil law (1998)

4. E. E. Gladkov, Actual problems of our time: science and society, 4(13) (2016)

5. E. E. Gladkov, Actual problems of our time: science and society, 3(12) (2013)

6. O. S. Ioffe, Selected works, 3 (2009)

7. S. A. Konakh, IN SITU, 3 (2017)

8. I. B. Novitsky, Roman law (2020)

9. G. T. Ovezov, Problems of Science and Education, 7(8) (2017)

10. D. M. Rassadin , A.A. Serov, L.E. Shirinkina, Economics and business: theory and practice, 7 (2016)

11. V. E. Rubanik, History of the state and law of Russia, 1 (2020)

12. E. A. Talabaev, Science. Society. State, 1(21) (2018)

13. Irina P. Chupina, Natalia N. Simachkova, Oksana S. Trotsenko, E3S Web of Conferences, 176, 06005 (2020) 